Article

\title{
Strategic Environmental Assessment of Port Plans in Italy: Experiences, Approaches, Tools
}

\author{
Maria Cerreta * and Pasquale De Toro \\ University of Naples "Federico II", Department of Conservation of Architectural and Environmental \\ Heritage, via Roma 402, I-80134 Naples, Italy; E-Mail: detoro@unina.it \\ * Author to whom correspondence should be addressed; E-Mail: cerreta@unina.it; \\ Tel.: +39-081-2538659; Fax: +39-081-2538649.
}

Received: 11 September 2012; in revised form: 22 October 2012 / Accepted: 26 October 2012 / Published: 1 November 2012

\begin{abstract}
Evaluation is increasingly important in decision-making processes for the sustainable planning and design of port plans. It acts as a support for plan preparation, for making values, interests and needs explicit, and for exploring the components of the decision-making process itself. Evaluation can be likened to an "implicit tool" that can integrate approaches, methodologies and models, adapting to the many needs revealed during the decision-making process. New sustainability challenges call for new approaches to creating frameworks for the analysis and evaluation of plans and projects that allow the integration of multidimensional goals and values. Utilizing some selected case studies of port plans in six Italian cities, this paper explores how environmental assessment can become a tool for dialog and interaction among different fields of expertise to support dynamic learning processes, knowledge management and the creation of shared choices, using suitable approaches and tools. In this view, Integrated Spatial Assessment (ISA) can be useful in supporting decision-making processes on different scales and institutional levels to stimulate dialog between technical and political evaluations, referring to complex values that are part of conflicting and changing realities in which it has become imperative to operate according to sustainability principles.
\end{abstract}

Keywords: Strategic Environmental Assessment; integrated assessment; dynamic spatial decision-making process; Integrated Spatial Assessment 


\section{Introduction}

According to Therivel and Partidário [1] a Strategic Environmental Assessment (SEA) can be defined as "the formalized, systematic and comprehensive process of evaluating the environmental impacts of a policy, plan or programme and its alternatives, including the preparation of a written report on the findings of that evaluation, and the use of these findings in publicly accountable decisionmaking." Indeed, European Directive 42/2001/EC, dating from 27 June, 2001 [2], concerns the assessment of the effects of some plans and programs on the environment, including port plans. The Environmental Report phase is critical for the assessment of plan effects. This document is part of the Plan and accompanies the entire process of its preparation and approval.

The Environmental Report must identify, describe and evaluate all significant effects that plan implementation might have on environmental and cultural heritage. It must examine reasonable alternatives, while taking into account the plan's goals and its geographical scope. The Environmental Report must include the information that can reasonably be required while taking into account current knowledge and assessment methods, plan content and level of detail, according to Annex I of the European Directive. Indeed, the Environmental Report can be considered a decision support instrument aimed at providing as detailed a picture as possible of the environmental impacts related to the implementation of a plan, policy or program. In the case of plans, the Environmental Report must contain sufficient information to assess the acceptability of the impacts, and consequently to propose suitable modifications and mitigations [3].

McLauchlan and João [4] underlined that in the EU, the practical application of SEA is influenced by how the provisions of the SEA Directive have been transposed into the laws of individual EU member states. Each member state produced SEA regulations that reflected their own system of planning and governance in order to provide for a high level of protection of the environment and to contribute to the integration of environmental considerations into the preparation and adoption of plans and programs. At the same time, SEA literature has been critically examined to determine whether or not SEA influences the decision-making process, with specific attention to what is an "effective" SEA [5-11], taking into account the different typologies of plans and programs.

This paper focuses on the SEA modalities used in the development of some recent port plans in Italy approved in 2010 and 2011, according to the European Directive. The purpose is to analyze how SEAs ensure that options with important environmental effects are considered and if the effectiveness of a SEA is framed in terms of its contribution to the use of information relating to the environmental consequences of a proposed project, but also to the application of evaluative tools and instruments for the development of the decision-making process and the selection of the most environmentally correct options and/or adoption of necessary mitigation measures. At the same time, it can be relevant in identifying a methodological process able to improve the decision framework (Figure 1). 
Figure 1. Analysis of SEA processes.

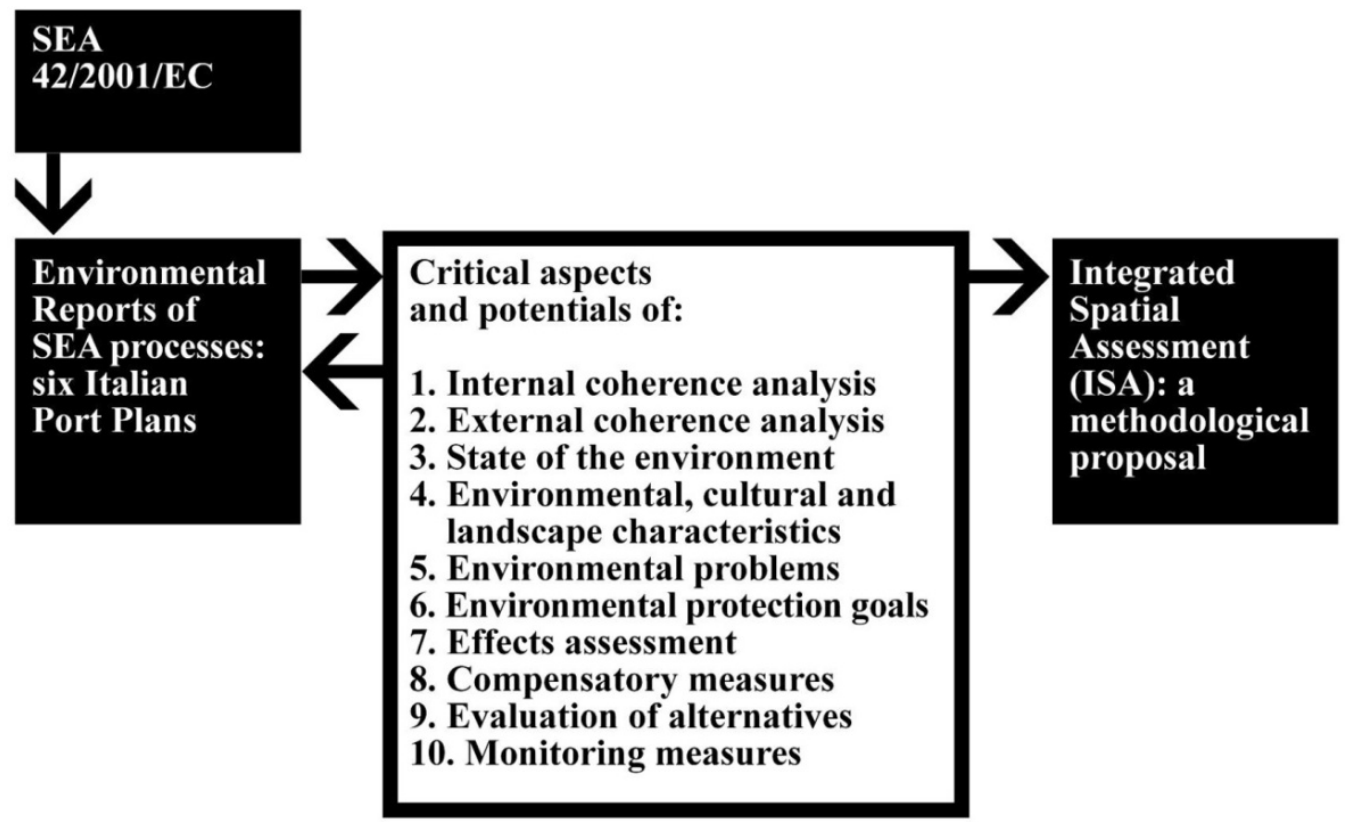

With particular regard to environmental effects assessment, we must consider that port development has the potential to significantly affect the following environmental components [12]: ecology and nature conservation; landscape; archaeology and cultural heritage; recreation and tourism; and, drainage and water quality. New activities in ports could give rise to visual effects, health effects such as illumination, noise and vibration, or environmental effects on air, water and soil quality. Moreover, when ports are situated in or near Sites of Community Importance (especially those in intertidal areas) the potential of port-related activities to significantly affect or disturb the site's priority species or habitats must be assessed [13]. In some cases, when ports propose seaward or landward development, they are already required to complete an Environmental Impact Assessment [14].

In any case, measuring changes in environmental status depends on:

- developing scientific understanding of the links between human activity and environmental change;

- identifying appropriate environmental performance indicators;

- putting effective monitoring schemes in place to detect changes in variables; and,

- having baseline data against which to assess changes in site status.

Such complex interactions require a collaborative approach between port authority, scientists and other interested parties. An additional complication is that many of the scientific aspects of these environmental issues are beyond current human understanding. Therefore, it is useful to break down a territory's environmental complexity into different components and interpret them through simple and reliable indicators [15].

In this view, it is necessary to develop suitable indicators that can consider different pollutants generated by port operations [16], not only in reference to water contamination but also to the urban dispersion of air pollutants originating from ships [17]. At the same time, we must consider that changes in coastal land use could also significantly alter the landscape [18]. The concept of landscape ecology provides an integrated approach and a challenge for studying the relationship between 
landscape patterns and changes in environmental conditions due to human land uses. The quantification of landscape patterns through various landscape (natural and artificial) indices can be used to describe the characteristics and fragments of landscape patterns. Such information can be used in evaluating the influence of human activities on coastal zones [19]. In particular, human use of ecosystem resources and services is increasing worldwide, generating pressures that alter ecosystem structure, functioning and ability to provide of services. Most of this information has a spatial component because geographical distribution of impacts plays a relevant role in determining how they are perceived by decision-makers, as well as by the affected stakeholders and the general public. Although this applies to all kinds of plans, it is particularly evident for land use plans and port plans, whose implications have an explicit spatial nature [3]. It is possible to develop a geospatial approach for modeling the complex relationships between multiple human pressures and coastal ecosystemic conditions. The implementation of a Geographic Information System (GIS) represents an important decision support tool for finding efficient management solutions in the face of complex interactions and great uncertainty [20].

The paper is structured as follows: Section 2 provides a description of the Strategic Environmental Assessment process, emphasizing the need to integrate the decision-making process to the SEA process by a multi-methodological framework. The SEA process and its application are analyzed in Section 3, considering six Environmental Reports for Italian ports that have completed the approvals process of their port plans (Cagliari, Numana (AN), Otranto (LE), Taranto, Termoli (CB) and Vasto $(\mathrm{CH})$ ). In Section 4, the Integrated Spatial Assessment (ISA) approach is proposed in order to define a dynamic spatial evaluative model according to a multidimensional perspective, aimed at providing technical guidance for SEA. Finally, Section 5 provides some conclusions and proposals for future applications and improvements.

\section{Strategic Environmental Assessment: A Multi-Methodological Framework}

In recent years, environmental assessment research and in particular Strategic Environmental Assessment (SEA) research and practice underline the need for explicit engagement with decision-making, ensuring its involvement as early as possible in the planning process. The "decisionoriented" approach was defined according to this perspective. This approach emphasizes the fact that SEA parallels the decision-making process, including its preparation. It considers the decision-making process itself as an iterative cycle of problem understanding, goal setting, solution identification, analysis, decision-making, evaluations, and learning feedback, and coming back to revised problem understanding, and renewed goals [21,22]. More recently, SEA has been increasingly valued and understood. Its use and applications in different situations and contexts has become greatly clarified, including the use of SEA in achieving sustainable development in relation to previously defined goals and targets. Indeed, there is increasing appreciation of SEA's tiered nature and the need to fit the process to specific policy, plan or program requirements. This means that SEA has become a mature instrument and can be applied extensively [6,7,10,11].

However, SEA is still not as widely known as one might possibly expect from this potentially very beneficial decision-making support instrument. SEA's positive role in effective decision-making processes should be better highlighted, focusing specific attention on SEA's simple, integrative and 
flexible nature and its positive role in helping to avoid wasting natural and financial resources. Indeed, SEA can follow the so-called "integrated evaluations" approach - a key tool for supporting the decision-making process especially when uncertainty, complexity and different and conflicting values are simultaneously present [23]. According to this approach, SEA should consider not only the input of data expressing the effects of different solutions, but should also be "open" to broad public participation in order to offer more information for the evaluation itself and, in addition, to ensure that the decision-making process and its results become more acceptable and shared [24]. Therefore, SEA constitutes an ongoing process that is iterative and interactive, multidisciplinary (respecting the issues addressed) and participative (respecting communities), recognizing the importance of technical indeterminacy and multiplicity of values.

Increasing attention to the SEA process and its articulation, as well as the definition of goals - starting from a knowledge-oriented context in the broadest sense-shows that it is necessary to apply SEA in the earliest stages of the decision-making process so that it can be truly effective in improving the organization of plan phases and render the evaluation operational. It also becomes necessary to determine the stage of the decision-making that is most appropriate for the integration of SEA approaches and techniques. From experience and practice, four models of interaction between SEA and planning process have been identified [5]. The first model identifies the assessment of effects as an essential SEA task. Analogously to Environmental Impact Assessment (EIA), this model considers SEA as a well-defined phase in the decision-making process. The second model defines two parallel courses of action. One is decision-oriented and the other evaluation oriented; both communicate only in certain stages. The third model identifies a course of integration in which the stages of the planning process parallel SEA phases in a relationship of feedback and constant interaction. The fourth model, however, considers SEA as a process that can compensate for the deficiency of planning with appropriate evaluation. Complete integration of SEA within the planning process requires correct understanding of the decision-making process in its different phases, along with the need to identify specific contributions of the different professional fields involved. Decisions are made after considering a number of different and sometimes conflicting points of view and variables in which environmental issues are only one of the aspects taken into account in an interdisciplinary manner. Developing a SEA process in an integrated and participatory way means considering how different points of view, components and values can contribute to the understanding of key issues and the selection of alternatives.

In order for integration to become effective, it must overcome the technical difficulties and internal rules of the SEA and planning processes. But it must also face the risk of excessive flexibility, according to which SEA must adapt to the characteristics of a specific decision-making process and a given physical context [25]. In fact, a SEA that is fully integrated with the decision-making process could lose its role as an independent and impartial process, as a tool for independent evaluation and auditing essential for guaranteeing the quality and substance of the procedure. Furthermore it is necessary to consider that SEA can take on different "forms" based on: the environmental sector concerned (transport, energy, waste, etc.), the administrative level involved (national, regional, provincial, local, etc.), and the strategic goals considered (policy, program, plan, etc.). Therefore, the structure of the SEA process as a tool to support decision-making should adapt to the type and content 
of the policy, plan or program in question and the relative procedural phases without compromising the specific nature of the approach itself.

At the same time, it is important to combine different techniques and tools within the same framework, integrating various evaluation tools - such as environmental, social and ethical balance sheets, and Economic Valuation, Input-Output Analysis, Life Cycle Assessment, Risk Assessment, Ecological Effects, Ecological Footprint, Mass/Energy Valuation, Multi-Criteria Decision-Aid Methods, Future Studies [26] — in order to define a multi-methodological framework that can analyze and tackle the different issues. In particular, some methods offer the possibility of combining Multi-Criteria Analysis and Multi-Group Analysis with Geographical Information Systems (GIS), Internet Technology, Spatial Decision Support Systems, Cellular Automata Models. Indeed, the integration of different evaluation models with GIS [27] becomes particularly important in the construction of a Dynamic Spatial Decision Support System. A wide variety of territorial information (social, economic and environmental) can be easily combined and related to the characteristics of the different land use options, facilitating the construction of appropriate indicators and improving impact forecasting, leading to a preference priority list of the various options. Integration of Multi-Criteria Analysis, Multi-Group Analysis and GIS can be exceptionally useful in the presence of strong environmental and social conflicts in which the role of local resources and actors, their relations and objectives can be considered structuring elements in the development of a dynamic spatial evaluative model [28-31]. Some interesting examples of integration among different and complementary methods and techniques in the spatial planning field have been proposed in which GIS is combined with evaluation tools and Planning Support Systems (PSS). A multi-methodological framework can be considered as the integration of four systems: a dynamic system (that can consider temporal evolution and changes over time); a deliberative system (that can include all stakeholder perspectives and points of view); a comprehensive system (that can take into account quantitative and qualitative aspects relating to different components); and, a spatial system (that can identify territorial effects, including their visualization). A multi-methodological decision support system can be characterized by the interaction of Knowledge Bases (KB), Relational Database Management Systems (RDBMS), Graphical User Interfaces (GUI), Geographic Information Systems (GIS), Multi-Criteria Analyses (MCA), and Multi-Group Analyses (MGA) [32].

\section{Environmental Assessment of Port Plans in Italy}

Six Environmental Reports for Italian ports that have completed the approvals process of their port plans were studied along with the concomitant SEA process: Cagliari, Numana (AN), Otranto (LE), Taranto, Termoli (CB) and Vasto $(\mathrm{CH})$ [33-38].

Firstly, we considered that the Directive 2001/42/EC on SEA contains instructions to carry out consultations with the public and authorities (associations, organizations, groups). In particular, the authorities shall be consulted when deciding on the scope and level of detail of the information which must be included in the Environmental Report. Afterward, the draft plan and the Environmental Report shall be made available to the authorities and the public, so that they can have an early and effective opportunity within appropriate time frames to express their opinion on the draft plan and the 
accompanying Environmental Report before the adoption of the plan or its submission to the legislative procedure.

Therefore, all Environmental Reports of the six plans contain specific information about the consultation process (Table 1). In all cases, the results consist of observations about the integration of certain environmental issues in the Reports and the change of some plan actions, considered unsatisfactory.

Table 1. Consultation process.

\begin{tabular}{lll}
\hline Environmental Reports & \multicolumn{1}{c}{ Participants } & \multicolumn{1}{c}{ Tools } \\
\hline Cagliari Port Plan & 12 Public authorities & Scoping meeting \\
\hline Numana Port Plan & 20 Public authorities & Decision meeting \\
\hline Otranto Port Plan & 13 Public authorities & $\begin{array}{l}\text { Decision meeting } \\
\text { Evaluation conference }\end{array}$ \\
\hline 11 Associations or organizations & Conferences \\
\hline Taranto Port Plan & 2 Public authorities & \\
& 8 Associations or organizations & Conferences \\
& 27 Public authorities & Technical tables \\
& & Thematic forums \\
\hline Vasto Port Plan & 7 Public authorities & Scoping meeting \\
\hline
\end{tabular}

On the basis of the consultation process, the plan objectives and the final actions were developed. For each port, the main objectives to be pursued are as follows:

- Cagliari Port Plan:

1. find broader and deeper stretches of water for the arrival of larger vessels;

2. provide new infrastructure in more suitable coastal zones;

3. implement the historic port area transformation with the change of its current role;

4. restructure the waterfront and the city-port interface;

5. revitalize the waterfront with greater integration with the border areas.

- Numana Port Plan:

1. secure the current dock and improve the existing entrance;

2. improve the water surface use;

3. improve port services;

4. integrate the port and the city.

- Otranto Port Plan:

1. rationalize the existing port areas;

2. build new interventions (defense and docks).

- Taranto Port Plan:

1. plan infrastructural, functional and operation development of the port acting for the economic growth of the area, and improving the environment and social people liveableness.

- Termoli Porto Plan:

1. organize and complete the port and defense works; 
2. build and organize infrastructure connections;

3. enhance the state-owned assets, the protected area and the marina;

4. localize tourist facilities;

5. relocate shipbuilding.

- Vasto Port Plan:

1. extend the existing port areas;

2. build new rail infrastructure connections;

3. build and adapt the existing structures;

4. create a new shape of the stretches of water (commercial, pleasure crafts, fishing) by changing the current planimetric structure;

5. identify areas for a new localization of services.

Therefore, the plans have some common features but also some specificities depending on the territorial context and their own functions, which influence the objectives and planned actions (Table 2). For example, the ports of Numana and Otranto are exclusively marinas, while the other ports offer a zoning that tries to separate the tourist function from the commercial one; in some cases there is also a zone of interaction between port and city. In all cases, the plans provide, in addition to the location of the various functions, specific interventions related to them (piers, docks, roads, parkings, buildings, etc.).

Table 2. Plan actions.

\begin{tabular}{|c|c|c|}
\hline Environmental Reports & Intervention areas & Plan actions (zoning) \\
\hline \multirow[t]{9}{*}{ Cagliari Port Plan } & Historic Port & Marina \\
\hline & & Green spaces and promenade \\
\hline & & Multipurpose center and services \\
\hline & & Pleasure crafts and big yachts \\
\hline & & Passengers terminal and port services \\
\hline & & Fishing port and port captain's office \\
\hline & Harbor & Containers terminal \\
\hline & & Freight terminal and shipyard \\
\hline & Western coastal zone & Tourism, sport and leisure \\
\hline \multirow[t]{4}{*}{ Numana Port Plan } & City-Port interaction & Services (trade, tourism, parking, etc.) \\
\hline & & Fishing \\
\hline & Operative Port & Marina \\
\hline & & Port services \\
\hline \multirow[t]{11}{*}{ Otranto Port Plan } & City-Port interaction & Port captain's office, customs and port authorities \\
\hline & & Trade \\
\hline & & Garaging and workshops \\
\hline & & Productive activities \\
\hline & & Bathing and shops \\
\hline & & $\begin{array}{l}\text { Urban parks, parkings and directional, cultural, } \\
\text { representative, commercial urban uses }\end{array}$ \\
\hline & Operative Port & Pleasure crafts \\
\hline & & Vintage boats moorings \\
\hline & & Commercial services, bunkering and fuel \\
\hline & & Check point and police \\
\hline & & Infrastructures \\
\hline
\end{tabular}


Table 2. Cont.

\begin{tabular}{|c|c|c|}
\hline Environmental Reports & Intervention areas & Plan actions (zoning) \\
\hline \multirow[t]{14}{*}{ Taranto Port Plan } & Territory-Port interaction & Urban-nautical function \\
\hline & & Passengers services \\
\hline & & Customs \\
\hline & & Environmental protection oasis \\
\hline & & Roads \\
\hline & & Port services \\
\hline & & Port-territory interface \\
\hline & Operative Port & Passengers services \\
\hline & & Trade \\
\hline & & Logistics \\
\hline & & Port services \\
\hline & & Liquid and bulk freights \\
\hline & & Industries \\
\hline & & Containers \\
\hline \multirow[t]{8}{*}{ Termoli Port Plan } & City-Port interaction & Marina \\
\hline & & Parking and green spaces \\
\hline & Operative Port & Defense and maneuvering structures \\
\hline & & Commercial port \\
\hline & & Ship repairs \\
\hline & & Fishing port \\
\hline & & Passengers terminal \\
\hline & & Public authorities \\
\hline \multirow[t]{8}{*}{ Vasto Port Plan } & Operative Port & Fishing boats and pleasure craft \\
\hline & & Ferries \\
\hline & & "Roll on-roll out" traffic \\
\hline & & Different freights \\
\hline & & Liquid and bulk freights \\
\hline & & Port services \\
\hline & & Buildings for port services and trade \\
\hline & & Environmental requalification and compensation \\
\hline
\end{tabular}

Taking into account the above perspective, all aspects of Annex I of the European Directive 42/2001/EC [2] were analyzed. It was observed that the plans have some aspects in common; for instance, all of the Environmental Reports devoted significant attention to the state of the environment by identifying a variety of environmental issues and related indicators. At the same time, all the Environmental Reports indicated port plan goals (often defining them as "general" goals and "specific" goals) and carried out an "analysis of coherence" between plan goals and those of other relevant plans and programs, and with environmental goals established on the international level. Starting from plan goals, specific Actions Plans were drawn up in which some critical aspects consider the assessment of the Actions' effects on the environment or evaluate the alternatives. In the following paragraphs, we will examine in detail the different approaches taken in relation to each point of the Annex I of the Directive. 
3.1. An Outline of the Contents, Main Objectives of the Plan and Relationship with Other Relevant Plans and Programs

Almost all of the Environmental Reports examined addressed this topic with the "analysis of internal coherence" (Table 3) and an "analysis of external coherence" (Table 4), even if the approaches to the two topics were different.

In the first case, a coherence check between general and specific plan goals and sustainability goals or between the goals and the plan actions were proposed. This approach does not seem very satisfactory for two reasons:

1. during the definition of plan goals, sustainability goals should not be isolated factors but should be integrated with plan goals;

2. during the definition of plan actions, these should derive from the defined goals and should therefore be intrinsically coherent.

Therefore, it might be useful to organize the planning process through the construction of a "decision tree," a hierarchical structure in which goals (general and specific, including sustainability goals) - and any strategies and concrete actions designed to achieve those goals - are coherently organized. In this way, starting from the very early stages of plan preparation, it could be possible to identify potential conflicts between different goals (or contradictions with strategies and actions) and thus modify them.

On the other hand, the analysis of external coherence was interpreted in most of the Environmental Reports as the verification of the coherence between the goals of other relevant plans and programs that involve the port area in some way and the goals upon which the port plan is based.

The rating scales used (qualitative) were different in all cases examined. A uniform approach could be proposed by simply clarifying relationships of "coherence," "indifference" and "incoherence" between the port plan goals and those of the other plans and programs considered. In this way, significant elements could be represented by both the coherence between goals which highlight shared strategies as well as by incoherence or contradictions, which can be seen as critical factors insofar as pursuing certain goals could undermine the achievement of others. However, incoherence does not affect, a priori, the possibility of pursuing certain goals but points out that, during the planning of specific interventions, it will be necessary to understand how to overcome the identified discrepancies. We must not, in any case, attribute negative significance to possible indifference since, on a whole, the elements defined as indeterminate are often consistent with the goals of other plans or programs in question even if some of the port plan goals do not have a direct relationship with a certain plan or program (due to sector-related specificity). Thus, it might be useful to conduct a comprehensive analysis, simultaneously taking into consideration all coherence matrices, in order to verify the frequency with which coherence and contradictions occur. 
Table 3. Internal coherence analysis.

\begin{tabular}{|c|c|c|}
\hline Environmental Reports & Approaches & Tools \\
\hline Cagliari Port Plan & $\begin{array}{l}\text { Verification of coherence } \\
\text { between general goals and } \\
\text { plan actions }\end{array}$ & $\begin{array}{l}\text { Coherence matrix containing general goals } \\
\text { (rows) and plan actions (columns), } \\
\text { highlighting the presence or absence of } \\
\text { coherent relationships }\end{array}$ \\
\hline Numana Port Plan & Not specified & Not specified \\
\hline Otranto Port Plan & $\begin{array}{l}\text { Verification of coherence } \\
\text { between specific goals and } \\
\text { plan sustainability goals }\end{array}$ & $\begin{array}{l}\text { Coherence matrix containing specific goals } \\
\text { (rows) and plan sustainability goals (columns). } \\
\text { Use of the following assessment scale: } \\
\text { (+) Total coherence } \\
\text { (/) Neutral } \\
\text { (-) Lack of coherence }\end{array}$ \\
\hline Taranto Port Plan & $\begin{array}{l}\text { Verification of coherence } \\
\text { between plan goals and actions }\end{array}$ & $\begin{array}{l}\text { Coherence matrix containing goals (rows) and } \\
\text { plan actions (columns), highlighting the } \\
\text { presence or absence of coherent relationships }\end{array}$ \\
\hline Termoli Port Plan & $\begin{array}{l}\text { Verification of coherence } \\
\text { between general goals and } \\
\text { plan sustainability goals }\end{array}$ & $\begin{array}{l}\text { Coherence matrix containing general goals } \\
\text { (rows) and plan sustainability goals (columns). } \\
\text { Use of the Logical Framework technique with } \\
\text { the following assessment scale: } \\
\text { (5) Direct coherence } \\
\text { (4) Indirect coherence } \\
\text { (3) Indifference } \\
\text { (2) Indirect incoherence } \\
\text { (1) Direct incoherence }\end{array}$ \\
\hline Vasto Port Plan & $\begin{array}{l}\text { Verification of coherence } \\
\text { between general goals and } \\
\text { plan actions }\end{array}$ & $\begin{array}{l}\text { Checklist containing plan goals. Use of the } \\
\text { following assessment scale: } \\
\text { (V) Goal reached satisfactorily } \\
\text { (X) Goal not reached satisfactorily }\end{array}$ \\
\hline
\end{tabular}

Table 4. External coherence analysis.

\begin{tabular}{lll}
\hline Environmental Reports & \multicolumn{1}{c}{ Approaches } & \multicolumn{1}{c}{ Tools } \\
\hline Cagliari Port Plan & $\begin{array}{l}\text { Identification of goals of regional, } \\
\text { provincial and municipal plans } \\
\text { concerning the port area }\end{array}$ & $\begin{array}{l}\text { Drafting of general and specific plan goals } \\
\text { (hierarchically organized), taking into account } \\
\text { the goals of the plans and programs studied }\end{array}$ \\
\hline Numana Port Plan & $\begin{array}{l}\text { Identification of goals of regional, } \\
\text { provincial and municipal plans }\end{array}$ & $\begin{array}{l}\text { Coherence matrix containing plan goals (rows) } \\
\text { and goals of the plans and programs studied } \\
\text { (columns). Use of the following assessment } \\
\text { concerning the port area. }\end{array}$ \\
& Verification of coherence in & scale: \\
relation to plan goals & (C) Coherent \\
& & (P) Pertinent \\
& (I) Incoherent \\
& (NP) Not pertinent
\end{tabular}


Table 4. Cont.

\begin{tabular}{|c|c|c|}
\hline Environmental Reports & Approaches & Tools \\
\hline Otranto Port Plan & $\begin{array}{l}\text { Identification of goals of regional, } \\
\text { provincial and municipal plans } \\
\text { concerning the port area. } \\
\text { Consistency check in relation to } \\
\text { plan goals }\end{array}$ & $\begin{array}{l}\text { Coherence matrix containing plan } \\
\text { sustainability goals (rows) and goals of the } \\
\text { plans and programs studied (columns). Use of } \\
\text { the following assessment scale: } \\
\text { (+) Total coherence } \\
\text { (/) Neutral } \\
\text { (-) Lack of coherence }\end{array}$ \\
\hline Taranto Port Plan & $\begin{array}{l}\text { Identification of goals of regional, } \\
\text { provincial and municipal plans } \\
\text { concerning the port area }\end{array}$ & Checklist for some sustainability criteria \\
\hline Termoli Port Plan & $\begin{array}{l}\text { Identification of goals of regional, } \\
\text { provincial and municipal plans } \\
\text { concerning the port area. } \\
\text { Verification of coherence in } \\
\text { relation to plan sustainability } \\
\text { goals }\end{array}$ & $\begin{array}{l}\text { Coherence matrix containing goals of the } \\
\text { plans and programs studied (rows) and plan } \\
\text { sustainability goals (columns). Use of the } \\
\text { following assessment scale: } \\
\text { (5) Direct coherence } \\
\text { (4) Indirect coherence } \\
\text { (3) Indifference } \\
\text { (2) Indirect coherence } \\
\text { (1) Direct coherence }\end{array}$ \\
\hline Vasto Port Plan & $\begin{array}{l}\text { Identification of goals of regional, } \\
\text { provincial and municipal plans } \\
\text { concerning the port area. } \\
\text { Consistency check in relation to } \\
\text { plan goals }\end{array}$ & $\begin{array}{l}\text { Coherence matrix containing general plan } \\
\text { goals (rows) and goals of the plans and } \\
\text { programs studied (columns). Use of the } \\
\text { following assessment scale: } \\
\text { (1) Coherent } \\
\text { (2) Cannot be evaluated } \\
\text { (3) Coherent with special dispensation }\end{array}$ \\
\hline
\end{tabular}

Such an approach was used in the Termoli Plan by applying the Logical Framework technique to deduce levels of cumulative coherence/incoherence starting from the qualitative data in the coherence matrices.

\subsection{The Relevant Aspects of the Current State of the Environment and the Likely Evolution Thereof without Implementation of the Plan}

In all cases, the state of the environment was described by identifying a set of "environmental components" whose characteristics were described in text as well as by qualitative and quantitative indicators (Table 5). The context in question was not only the port area itself but also its broader context. This means that the information available was often uneven and highly dependent on the territorial scale of each environmental component. The environmental components identified in each State of the Environment are explicated in Table 6. The selection of environmental components and relative indicators vary depending on the characteristics of the plan and its context. Furthermore, the words are often different and, in some cases, are considered merged. Therefore, from the comparison among the environmental reports it can be highlighted as some themes are recurring, while others are specific and sectoral. 
In order to proceed with a uniform structure of the data available, in three cases (Cagliari, Termoli and Vasto), specific indicators were explored. The unit of measurement and calculation methods was specified in order to obtain quantitative values. In two cases, the same indicators were also used for assessing alternatives and, in one case, for plan monitoring.

Table 5. State of the environment: Approaches.

\begin{tabular}{ll}
\hline Environmental Reports & \multicolumn{1}{c}{ Approaches } \\
\hline Cagliari Port Plan & $\begin{array}{l}\text { Description of the State of the Environment in reference to } 11 \\
\text { environmental components. Identification of } 63 \text { available } \\
\text { quantitative indicators }\end{array}$ \\
\hline Numana Port Plan & $\begin{array}{l}\text { Description of the State of the Environment in reference to } 10 \\
\text { environmental components }\end{array}$ \\
\hline Otranto Port Plan & $\begin{array}{l}\text { Description of the State of the Environment in reference to } 9 \\
\text { environmental components }\end{array}$ \\
\hline Taranto Port Plan & $\begin{array}{l}\text { Description of the State of the Environment in reference to } 14 \\
\text { environmental components }\end{array}$ \\
\hline Termoli Port Plan & $\begin{array}{l}\text { Description of the State of the Environment in reference to } 6 \\
\text { environmental components. } \\
\text { Identification of } 18 \text { available quantitative indicators, used for the } \\
\text { assessment of plan alternatives and monitoring actions }\end{array}$ \\
\hline Dasto Port Plan & $\begin{array}{l}\text { Description of the State of the Environment in reference to } 14 \\
\text { environmental components. Identification of 23 available } \\
\text { quantitative indicators, used for the assessment of plan alternatives } \\
\text { and monitoring actions }\end{array}$ \\
\hline
\end{tabular}

In general, it is necessary to identify a set of quantitative indicators that can describe the characteristics of the environmental components and that can also be used in the stages of predicting plan effects, assessing alternatives and monitoring. To do this, all available indicators (for all environmental components) can be structured according to models frequently used in Environmental Reporting. Each indicator can be introduced into "synoptic chart" for each environmental component showing:

- the name of the indicator and its unit of measurement;

- the part of the DPSIR model (Driving forces, Pressures, State, Impacts, Responses) to which it belongs;

- the revision cycle, meaning the information on the length of time between two successive publications of indicator data (annual, biennial, etc.);

- spatial coverage, meaning the level of geographical coverage of the collected data used to populate the indicator (national, regional, provincial, municipal, river basin, etc.);

- temporal coverage, meaning the reference period of the data populating the indicator and/or available time series;

- indicator status and trend, providing a brief assessment of the phenomenon and the achievement of legislated goals that can be deduced from indicator values. 
Table 6. State of the environment: Environmental components.

\section{Environmental Components in Environmental Reports}

\begin{tabular}{|c|c|c|c|c|c|}
\hline Cagliari Port Plan & Numana Port Plan & Otranto Port Plan & Taranto Port Plan & Termoli Port Plan & Vasto Port Plan \\
\hline Climate & Climate change & - & Climate & - & - \\
\hline Air & Air & $\begin{array}{l}\text { Atmosphere and } \\
\text { climate }\end{array}$ & Air quality & Air & Atmosphere \\
\hline Water & Water & Water resources & $\begin{array}{c}\text { Marine conditions } \\
\text { Quality of sea } \\
\text { waters } \\
\text { Aquatic ecosystems } \\
\text { Quality of } \\
\text { superficial } \\
\text { terrestrial waters } \\
\text { Benthic } \\
\text { communities } \\
\end{array}$ & - & $\begin{array}{c}\text { Water environment } \\
\text { Aquatic ecosystems } \\
\text { and biotic } \\
\text { communities }\end{array}$ \\
\hline Soil and subsoil & Soil and subsoil & $\begin{array}{l}\text { Geology and } \\
\text { morphology }\end{array}$ & $\begin{array}{l}\text { Soil and subsoil } \\
\text { Sediment } \\
\text { characteristics }\end{array}$ & Land use & Soil and subsoil \\
\hline $\begin{array}{c}\text { Flora, fauna and } \\
\text { biodiversity }\end{array}$ & - & $\begin{array}{c}\text { Vegetation, flora, } \\
\text { fauna } \\
\text { Biocenosis }\end{array}$ & $\begin{array}{l}\text { Land flora and } \\
\text { fauna } \\
\text { Terrestrial } \\
\text { ecosystems }\end{array}$ & - & $\begin{array}{c}\text { Flora and } \\
\text { vegetation } \\
\text { Fauna } \\
\text { Terrestrial } \\
\text { ecosystems and } \\
\text { biotic communities }\end{array}$ \\
\hline Landscape & $\begin{array}{l}\text { Biodiversity and } \\
\text { landscape }\end{array}$ & $\begin{array}{l}\text { Landscape and } \\
\text { cultural heritage }\end{array}$ & Landscape & $\begin{array}{l}\text { Perception and } \\
\text { landscape }\end{array}$ & Landscape \\
\hline $\begin{array}{c}\text { Historic, } \\
\text { architectural and } \\
\text { archeological } \\
\text { heritage }\end{array}$ & $\begin{array}{c}\text { Historic, } \\
\text { architectural and } \\
\text { archeological assets }\end{array}$ & - & $\begin{array}{c}\text { Historic, } \\
\text { architectural and } \\
\text { archeological } \\
\text { heritage }\end{array}$ & - & Cultural heritage \\
\hline
\end{tabular}

\begin{tabular}{cccccc}
\hline Physical pollutants & - & - & - & - & Light pollution \\
\hline $\begin{array}{c}\text { Economy and } \\
\text { society }\end{array}$ & - & - & $\begin{array}{c}\text { Human ecosystems } \\
\text { and socioeconomic } \\
\text { aspects }\end{array}$ & - & - \\
\hline Mobility & - & Accessibility & - & Transportation & - \\
\hline $\begin{array}{c}\text { Underground } \\
\text { utilities }\end{array}$ & - & - & - & - & - \\
\hline- & $\begin{array}{c}\text { Population and } \\
\text { human health }\end{array}$ & $\begin{array}{c}\text { Public health and } \\
\text { infrastructure }\end{array}$ & - & Accidents & - \\
\hline- & Tourism & - & - & - & - \\
\hline- & Energy & - & - & - & Energy \\
\hline- & Waste & - & - & Waste & Waste \\
\hline- & - & $\begin{array}{c}\text { Noise and } \\
\text { vibrations }\end{array}$ & - & Noise & Noise and \\
vibrations
\end{tabular}

In particular, in the subsequent evaluation and monitoring system, some indicators selected to describe the state of the environment can be used (the most significant in relation to plan actions). In this way, the entire process would be highly consistent insofar as it would refer to the same framework 
and could be verified in relation to changes that might occur as a result of plan implementation (and the possible alternatives identified).

In this light, environmental indicators play a key role not only in the ex-ante evaluation of the effects of the actions foreseen in the plan, but also in the subsequent monitoring phase (in which it is necessary to identify a specific set of indicators) and the assessment of hypothetical project alternatives (for example, regarding location or function).

\subsection{The Environmental Characteristics of Areas Likely to Be Significantly Affected}

The approaches to this aspect were varied. However, reference was made to specific environmental components characterizing the different contexts (Table 7). The descriptions of the cultural, landscape and environmental features could be enriched by the use of an appropriate Geographic Information System in order to associate an indicator's value (or an environmental index) with each spatial element characterizing the port area. The possibility of obtaining the "spatial" distribution of indicator values would allow their use not only in the fact-finding phase, but above all in the definition and assessment of alternatives, operating appropriate simulations of variations in indicator value resulting from the implementation of the plan assumptions.

Table 7. Environmental, cultural and landscape characteristics.

\begin{tabular}{lll}
\hline Environmental Reports & \multicolumn{1}{c}{ Approaches } & \multicolumn{1}{c}{ Environmental Components } \\
\hline Cagliari Port Plan & $\begin{array}{l}\text { Drafting of a map of critical } \\
\text { elements and emergencies }\end{array}$ & $\begin{array}{l}\text { Surface water } \\
\text { Land use } \\
\text { Geology }\end{array}$ \\
& & Flora, fauna and biodiversity \\
& & Landscape, architectural, and \\
& & archaeological heritage \\
& & Socioeconomic aspects \\
& & Mobility \\
Numana Port Plan & Identification of vulnerable & Climate, air quality and noise \\
& environmental units & Natural and ecosystemic units (terrestrial \\
& & and marine) \\
& & Hydro/geomorphological units (terrestrial \\
& & and marine) \\
\hline Otranto Port Plan & Not specified & Not specified \\
\hline Taranto Port Plan & Not specified & Not specified \\
\hline Termoli Port Plan & Description of environmental & Greenhouse gas emissions \\
& characteristics & Emissions of air pollutants from transport \\
& & Accidents \\
& & Waste from road vehicles \\
\cline { 2 - 3 } & Description of cultural and & Historic and established settlements \\
& Transformations underway \\
& landscape characteristics & Vegetation characteristics \\
& & Coastal waters \\
\hline & & Not specified \\
\hline
\end{tabular}




\subsection{Any Existing Environmental Problems Which Are Relevant to the Plan Including, in Particular,} Those Relating to Any Areas of a Specific Environmental Importance

The different Environmental Reports referred mainly to issues regarding possible interference of plan choices with areas of particular naturalistic importance (Table 8), such as Sites of Community Importance (introduced by Directive 92/43/ECC [13]) and Special Protection Areas (introduced by Directive 79/409/EEC [39]).

Indeed, Article 6 of Directive 92/43/ECC [13] (also known as the "Habitat" Directive) provides that any plan or project not directly connected to the management of the site but likely to have a significant effect thereon, either individually or together with other plans or projects, shall be subject to appropriate "assessment of its implications" for the site in view of the site's conservation objectives.

Therefore, when the plan reference area (not strictly the port area) was affected by/affects Sites of Community Importance and Special Protection Areas, a specific study concerning the natural features of these areas (and related environmental problems) was conducted. Subsequently, the effects of plan actions on the sites' environmental components were evaluated.

In particular, in the case of Cagliari Port Plan, new commercial functions are localized in an area which is partially internal to a Site of Community Importance and to a Special Protection Area. The environmental assessment has shown that it is an area already characterized by land artificialization with no flora and fauna species of value. Therefore, this area is suitable for the new use and, in any case, have been provided specific migration measures (creation of a buffer zone and planting of autochthonous species) to facilitate the ecological connections.

The Port of Otranto border is external to Sites of Community Importance and Special Protection Areas, but there is a terrestrial Sites of Community Importance at a distance of $250 \mathrm{~m}$ from the port and a marine site lapping against the port. The environmental assessment regarding the marine site examined the possible interference of the plan actions with biotic, abiotic and landscape components, both during the construction and operational phases. It has been detected only a few nonsignificant effects in the construction phase (dust, noise, sediment) and have been identified some appropriate mitigation measures to reduce the possible negative effects.

In the case of the Port of Taranto, the environmental characteristics of four Sites of Community Importance and a Special Protection Areas regarding the coastal area but external to the port perimeter have been described; however, no specific environmental assessment for these sites has been carried out.

The Port of Termoli is also external to this type of protected area, but an environmental assessment about the possible interference with a Sites of Community Importance and a Special Protection Areas close to the port was conducted. To reduce the possible interferences some mitigation measures regarding noise and vibration coming from vehicular traffic, the protection of biodiversity (by means of environmentally friendly materials and planting native species), landscape and visual impacts using barrier plants have been developed.

Finally, for the Port of Vasto, both a Site of Community Importance close to the port and a site directly affected by the zoning of the new port plan, were considered with the reorganization of the basin and the docks, and the construction of a new railway infrastructure in mind. The environmental assessment has examined the interference on habitats and species of flora and fauna (both in the 
construction and operational phase). However, the area included in the Site of Community Interest is already occupied, for the most part, by the existing port; the environmental assessment results have significantly influenced the morphology of the new port, advancing the coastline and creating dunes characterized by different habitats of Community interest. In general, depending on the different contexts, the identification of environmental problems that might affect the port area should not only refer to natural ecosystems but also other territorial and environmental aspects (waste, remediation, electromagnetism, etc.).

Table 8. Environmental problems.

\begin{tabular}{|c|c|c|}
\hline Environmental Reports & Approaches & Tools \\
\hline Cagliari Port Plan & $\begin{array}{l}\text { Description of the environmental } \\
\text { characteristics of the Site of Community } \\
\text { Importance and the Special Protected } \\
\text { Area concerning directly the port area }\end{array}$ & Evaluation of environmental effects \\
\hline Numana Port Plan & $\begin{array}{l}\text { Definition of the area of influence of the } \\
\text { port plan }\end{array}$ & $\begin{array}{l}\text { Definition of potential interactions of } \\
\text { the port plan with environmental and } \\
\text { territorial components }\end{array}$ \\
\hline Otranto Port Plan & $\begin{array}{l}\text { Description of the environmental } \\
\text { characteristics of the Site of Community } \\
\text { Importance closed to the port }\end{array}$ & Evaluation of environmental effects \\
\hline Taranto Port Plan & $\begin{array}{l}\text { Description of the environmental } \\
\text { characteristics of Sites of Community } \\
\text { Importance and Special Protected Areas } \\
\text { concerning the coastal area }\end{array}$ & Not specified \\
\hline Termoli Port Plan & $\begin{array}{l}\text { Description of the environmental } \\
\text { characteristics of the four Sites of } \\
\text { Community Importance and the Special } \\
\text { Protected Area closed to the port }\end{array}$ & Evaluation of environmental effects \\
\hline Vasto Port Plan & $\begin{array}{l}\text { Description of the environmental } \\
\text { characteristics of the Site of Community } \\
\text { Importance concerning directly the port } \\
\text { area and the site closed to the port }\end{array}$ & Evaluation of environmental effects \\
\hline
\end{tabular}

Table 9. Environmental protection goals.

\begin{tabular}{|c|c|c|}
\hline Environmental Reports & Approaches & Tools \\
\hline Cagliari Port Plan & $\begin{array}{l}\text { Identification of sustainability goals in } \\
\text { reference to: } \\
-1 \text { UN document } \\
-1 \text { UE document } \\
-1 \text { national document }\end{array}$ & $\begin{array}{l}\text { Development of plan sustainability } \\
\text { goals (for each environmental } \\
\text { component) starting from the goals } \\
\text { contained in the documents studied }\end{array}$ \\
\hline Numana Port Plan & $\begin{array}{l}\text { Identification of sustainability goals in } \\
\text { reference to: } \\
-1 \text { regional document }\end{array}$ & $\begin{array}{l}\text { Development of plan sustainability } \\
\text { goals (for each environmental } \\
\text { component) starting from the goals } \\
\text { contained in the document studied }\end{array}$ \\
\hline
\end{tabular}


Table 9. Cont.

\begin{tabular}{lll}
\hline Environmental Reports & \multicolumn{1}{c}{ Approaches } & \multicolumn{1}{c}{ Tools } \\
\hline Otranto Port Plan & $\begin{array}{l}\text { Identification of sustainability goals in } \\
\text { reference to: }\end{array}$ & $\begin{array}{l}\text { Development of plan sustainability } \\
\text { goals (for each environmental } \\
\text { component) starting from the goals } \\
\end{array}$ \\
& -7 UE documents & contained in the documents studied \\
& -1 national document & \\
\hline Taranto Port Plan & Not specified & Not specified \\
\hline Termoli Port Plan & Identification of sustainability goals in & $\begin{array}{l}\text { Development of plan sustainability } \\
\text { goals starting from the goals }\end{array}$ \\
& -20 UE documents & contained in the documents studied \\
\hline Vasto Port Plan & Not specified & Not specified \\
\hline
\end{tabular}

3.5. The Environmental Protection Objectives, Established at International, Community or Member State Level, Which Are Relevant to the Plan and the Way Those Objectives and Any Environmental Considerations Have Been Taken Into Account During Its Preparation

Recent international and national sustainable development policies reveal several general criteria and goals that can be used to define local sustainability goals. This approach was followed by most of the port plans in defining their sustainability goals in relation to each environmental component (Table 9). In this case, an "analysis of external coherence" would be helpful. This analysis is understood as the verification of the coherence between international/national sustainability goals and those upon which the port plan is based, illustrating (in qualitative terms) current "coherence," "indifference" and "incoherence" conditions, even through frequency analysis.

3.6. The Likely Significant Effects on the Environment Include Issues Such as Biodiversity, Population, Human Health, Fauna, Flora, Soil, Water, Air, Climatic Factors, Material Assets, Cultural Heritage, Including Architectural and Archaeological Heritage, Landscape and the Interrelationship between the Above Factors

The assessment of the environmental effects of plan actions is the central element of any Strategic Environmental Assessment. The Environmental Reports identified environmental components that could be influenced by the plan and to deploy instruments to describe these effects (Table 10).

In terms of the choice of environmental components, only in two cases (Termoli and Vasto) was reference made to the same components used in the description of the state of the environment. This approach is certainly preferable since evaluation should focus on the changes in given aspects of the environmental components that might occur as a result of plan implementation. In this way, it could be possible to compare existing conditions with conditions post-plan implementation, even in reference to more than one project alternative.

In these two cases, quantitative assessment of effects using specific forecasting models for each indicator was carried out. Furthermore, the attempt to define cumulative effects responds better to the dictates of Directive 42/2001/EC which states that these effects should include secondary, cumulative, synergistic, short, medium and long-term permanent and temporary, positive and negative effects. 
Table 10. Effects assessment.

\begin{tabular}{|c|c|c|}
\hline Environmental Reports & Environmental Components & Tools \\
\hline Cagliari Port Plan & $\begin{array}{l}\text { Air, Water, Soil and subsoil, Flora, } \\
\text { fauna and biodiversity, Landscape, } \\
\text { Historical, architectural and } \\
\text { archaeological heritage, Noise, } \\
\text { Electromagnetism, Light pollution, } \\
\text { Risk, Socioeconomic aspects, } \\
\text { Waste, Mobility, Underground } \\
\text { utilities }\end{array}$ & $\begin{array}{l}\text { Impact matrix containing plan actions (rows) } \\
\text { and emergencies subdivided into } \\
\text { environmental issues (columns). Qualitative } \\
\text { assessment of the effects using the following } \\
\text { scale: } \\
\text { (++) Potential impact-positive } \\
\text { (+) Potential impact-slightly positive } \\
(?) \text { Potential impact-uncertain } \\
(-) \text { Potential impact-slightly negative } \\
(--) \text { Potential impact-negative }\end{array}$ \\
\hline Numana Port Plan & $\begin{array}{l}\text { Biodiversity and landscape, Soil } \\
\text { and subsoil, Climate change, } \\
\text { Population and human health, } \\
\text { Water, Air, Waste }\end{array}$ & $\begin{array}{l}\text { Qualitative assessment of all plan actions in } \\
\text { reference to each environmental theme using } \\
\text { the following scale: } \\
(+++) \text { Very significant positive effect } \\
(++) \quad \text { Significant positive effect } \\
(+) \quad \text { Insignificant positive effect } \\
(-) \quad \text { Insignificant negative effect } \\
(--) \quad \text { Significant negative effect } \\
(---) \quad \text { Very significant negative effect. } \\
\text { Qualitative assessment of the cumulative } \\
\text { effects }\end{array}$ \\
\hline Otranto Port Plan & $\begin{array}{l}\text { Air, Water, Soil and subsoil, Waste, } \\
\text { Natural ecosystems, Urban } \\
\text { environment, Landscape, Historical } \\
\text { and cultural heritage, Population } \\
\text { and human health }\end{array}$ & $\begin{array}{l}\text { Impact matrix containing specific plan goals } \\
\text { (rows) and environmental components } \\
\text { (columns). Qualitative assessment of effects } \\
\text { using the following scale: } \\
\text { (+) Positive impact } \\
\text { (-) Negative impact } \\
\text { (?) Uncertain impact } \\
\text { (/) Insignificant impact }\end{array}$ \\
\hline Taranto Port Plan & $\begin{array}{l}\text { Atmosphere, Terrestrial and marine } \\
\text { aquatic environment, Soil and } \\
\text { subsoil, Vegetation, flora, fauna } \\
\text { and terrestrial ecosystems, Marine } \\
\text { ecosystem, Human ecosystems and } \\
\text { socioeconomic aspects, Landscape, } \\
\text { Historical, architectural and } \\
\text { archaeological heritage }\end{array}$ & $\begin{array}{l}\text { Description of possible effects for each } \\
\text { environmental component }\end{array}$ \\
\hline Termoli Port Plan & $\begin{array}{l}\text { Air, Noise, Land use, Perception } \\
\text { and landscape, Waste transport, } \\
\text { Accidents }\end{array}$ & $\begin{array}{l}\text { Quantitative assessment of cumulative effects } \\
\text { (2030) for } 3 \text { alternative scenarios in reference } \\
\text { to each environmental component using the } \\
\text { same indicators as state of the environment. } \\
\text { The values of the cumulative effects (for each } \\
\text { indicator) are normalized on a scale from } 0-1 \\
\text { through the construction of a spider chart for } \\
\text { each environmental component }\end{array}$ \\
\hline
\end{tabular}


Table 10. Cont.

\begin{tabular}{|c|c|c|}
\hline Environmental Reports & Environmental Components & Tools \\
\hline Vasto Port Plan & $\begin{array}{l}\text { Aquatic environment, Soil and } \\
\text { subsoil, Atmosphere, Noise and } \\
\text { vibrations, Flora and vegetation, } \\
\text { Fauna, Marine ecosystems and } \\
\text { biotic communities, Terrestrial } \\
\text { ecosystems and biotic communities, } \\
\text { Public health and environmental } \\
\text { sustainability, Energy, Light } \\
\text { pollution, Waste, Landscape, } \\
\text { Cultural heritage }\end{array}$ & $\begin{array}{l}\text { Quantitative assessment of alternatives for the } \\
\text { reconfiguration of the port basin with respect to } \\
\text { each environmental component, using the same } \\
\text { indicators as the state of the environment. } \\
\text { The values of the cumulative effects are } \\
\text { "weighted" (according to the importance } \\
\text { attributed to each environmental component) } \\
\text { calculating the "overall sustainability" of each } \\
\text { alternative }\end{array}$ \\
\hline
\end{tabular}

3.7. The Measures Envisaged to Prevent, Reduce and as Fully as Possible Offset any Significant Adverse Effects on the Environment of Implementing the Plan

Almost all of the Environmental Reports sought to identify requirements, guidelines or actions to compensate for possible negative plan effects (Table 11). To this end, it might be useful to develop appropriate "in-depth charts" for each environmental component relating to actions that could result in negative effects. In addition to the actions, these charts should indicate the environmental components involved, related problems, considerations and suggestions for mitigating and compensating adverse effects and the relevant professional skills necessary to carry them out.

Table 11. Mitigation and compensatory measures.

\begin{tabular}{lll}
\hline Environmental Reports & \multicolumn{1}{c}{ Approaches } & \multicolumn{1}{c}{ Actions } \\
\hline Cagliari Port Plan & $\begin{array}{l}\text { Development of } \\
\text { guidelines for the }\end{array}$ & Indication of specific requirements for certain project \\
& categories in relation to: \\
& & - protection of water resources, beaches and soil \\
& - protection of flora-fauna and landscape \\
& - protection of historic/ high-quality buildings and \\
& \\
& - enjoyment of places \\
& - protection of archaeological heritage \\
& pollution; \\
& - protection of acoustic conditions \\
& - environmental protection in the construction phase; \\
Development of & - safety \\
guidelines for plan & Indication of specific guidelines for the sustainability of \\
sustainability & the following environmental components: \\
& - biodiversity and landscape \\
& - soil and subsoil \\
& - cultural and archaeological heritage \\
& - climate change \\
& - population and human health \\
& - air \\
& - water \\
\hline
\end{tabular}


Table 11. Cont.

\begin{tabular}{|c|c|c|}
\hline Environmental Reports & Approaches & Actions \\
\hline Otranto Port Plan & $\begin{array}{l}\text { Identification of } \\
\text { compensatory measure } \\
\text { to avoid negative effects } \\
\text { on ecosystems }\end{array}$ & $\begin{array}{l}\text { Indication of solutions to mitigate effects relating to: } \\
\text { - dust } \\
\text { - noise diffusion } \\
\text { - lack of port water recycling }\end{array}$ \\
\hline Taranto Port Plan & Not specified & Not specified \\
\hline Termoli Port Plan & $\begin{array}{l}\text { Application of } \\
\text { techniques to mitigate } \\
\text { environmental effects of } \\
\text { the construction of } \\
\text { transport infrastructure } \\
\text { in contexts of particular } \\
\text { environmental value }\end{array}$ & $\begin{array}{l}\text { Indication of specific measures: } \\
\text { - port design optimization for reducing the risk of } \\
\text { accidents (simulations of naval maneuvers) } \\
\text { - port design optimization for containment of sediment } \\
\text { (application of the LITDRIFT model) } \\
\text { - measures to mitigate the effects of noise and vibration } \\
\text { from traffic } \\
\text { - mitigation measures for the conservation of } \\
\text { biodiversity } \\
\text { - mitigation measures for perception/landscape effects }\end{array}$ \\
\hline Vasto Port Plan & $\begin{array}{l}\text { Identification of } \\
\text { compensatory and } \\
\text { sustainability measures }\end{array}$ & $\begin{array}{l}\text { Indication of specific interventions: } \\
\text { - environmental rehabilitation of embankments } \\
\text { - creation of a green belt } \\
\text { - use of low-consumption lighting systems } \\
\text { - use of criteria and environmentally sustainable } \\
\text { construction and technology } \\
\text { - construction of renewable energy production plants }\end{array}$ \\
\hline
\end{tabular}

3.8. An Outline of the Reasons for Selecting the Alternatives Dealt With, and a Description of How the Assessment Was Undertaken, Including Any Difficulties (Such as Technical Deficiencies or Lack of Know-How) Encountered in Compiling the Required Information

The development of alternatives and their evaluation is now one of the most important and innovative aspects in drafting a port plan. It is particularly important not only to confront the final plan proposal with nonintervention conditions (Table 12), but also to evaluate different hypotheses (in terms of location, dimension or function) using quantitative indicators (as in the Termoli and Vasto cases).

Multi-criteria evaluation methods can also be useful in creating preference rankings between the different options. In particular, the use of multi-criteria methods is based on a preliminary "impact analysis," which refers to the forecasting of all effects of each alternative with respect to any environmental issues as they unfold over time. These effects can be expressed on different scales of assessment, using dimensionless indices. Therefore, a multi-criteria approach allows the systematic construction of impact matrices and the transformation of these qualitative-quantitative matrices into the possibility of comparing alternatives.

In addition, the integration of multi-criteria evaluation methods and Geographical Information Systems is important in terms of research and practical applications, even within Strategic 
Environmental Assessment, giving rise to a "spatial multi-criteria analysis" in which evaluation results are specific for each of the port area's territorial and environmental component.

Table 12. Evaluation of alternatives.

\begin{tabular}{|c|c|c|}
\hline Environmental Reports & Approaches & Tools \\
\hline Cagliari Port Plan & $\begin{array}{l}\text { Identification of possible use } \\
\text { locations }\end{array}$ & Interviews with the population \\
\hline Numana Port Plan & $\begin{array}{l}\text { Evaluation of } 2 \text { alternatives } \\
\text { 1. Alternative } 0 \text { (nonintervention) } \\
\text { 2. Definitive plan proposal }\end{array}$ & $\begin{array}{l}\text { Impact matrix containing environmental } \\
\text { components (rows) and the two alternatives } \\
\text { (columns) } \\
\text { Qualitative assessment of effects }\end{array}$ \\
\hline Otranto Port Plan & $\begin{array}{l}\text { Evaluation of } 2 \text { alternatives } \\
\text { 1. Alternative } 0 \text { (nonintervention) } \\
\text { 2. Definitive plan proposal }\end{array}$ & $\begin{array}{l}\text { Impact matrix containing environmental } \\
\text { components (rows) and the two alternatives } \\
\text { (columns) } \\
\text { Qualitative assessment of effects }\end{array}$ \\
\hline Taranto Port Plan & $\begin{array}{l}\text { Identification of possible project } \\
\text { choices }\end{array}$ & $\begin{array}{l}\text { Description of possible project choices in } \\
\text { relation to plan goals }\end{array}$ \\
\hline Termoli Port Plan & $\begin{array}{l}\text { Evaluation of } 2 \text { alternative } \\
\text { programmatic scenarios, each of } \\
\text { which is representative of a group } \\
\text { of alternative hypotheses for the } \\
\text { port and the reference scenario: } \\
\text { 1. Reference scenario } \\
\text { (nonintervention) } \\
\text { 2. Aggregate scenario } \\
\text { 3. Disaggregated scenario }\end{array}$ & $\begin{array}{l}\text { Impact matrix (2030) containing the same } \\
\text { indicators (rows) used in the description of the } \\
\text { state of the environment and scenarios } \\
\text { (columns). Correlation matrix in which the } \\
\text { values of the indicators are normalized on a } \\
\text { scale from } 0-1 \text { obtaining a spider chart for } \\
\text { each environmental component }\end{array}$ \\
\hline Vasto Port Plan & $\begin{array}{l}\text { Evaluation of } 4 \text { alternatives for } \\
\text { the reconfiguration of the port } \\
\text { basin, with relative railway lines } \\
\text { and upgrading of open space: } \\
\text { 1. Port Configuration A } \\
\text { 2. Port Configuration C } \\
\text { 3. Port Configuration } 6 \\
\text { 4. Port Configuration PRP2007 }\end{array}$ & $\begin{array}{l}\text { Impact matrix containing alternatives (rows) } \\
\text { and the same indicators (columns) as the state } \\
\text { of the environment } \\
\text { Quantitative assessment of indicator values }\end{array}$ \\
\hline
\end{tabular}

\subsection{A Description of the Measures Envisaged Concerning Monitoring}

Monitoring is an important aspect of Strategic Environmental Assessment. It is a proactive phase that provides indications for the progressive realignment of plan content to environmental protection goals, establishing specific corrective actions. In this sense, monitoring is a complex and multifaceted activity. It does not imply the mere collection and updating of information but is a decision support activity connected to assessment analysis.

For this purpose, the various Environmental Reports identified a "set of priority indicators" selected from the most significant ones, enabling the creation of a specific "monitoring chart" (Table 13). For each indicator, relevant information (such as the unit of measurement, the time frame for 
verification, the environmental authority in charge of the audit, the environmental components involved, and sustainability goal) was indicated.

Table 13. Monitoring measures.

\begin{tabular}{|c|c|c|}
\hline Environmental Reports & Approaches & Tools \\
\hline Cagliari Port Plan & $\begin{array}{l}\text { Identification of } 30 \text { monitoring } \\
\text { indicators }\end{array}$ & $\begin{array}{l}\text { Monitoring chart specifying (for each } \\
\text { indicator): unit of measurement, test } \\
\text { period, regulating authority, } \\
\text { environmental components and goals }\end{array}$ \\
\hline Numana Port Plan & $\begin{array}{l}\text { Identification of } 14 \text { monitoring } \\
\text { indicators }\end{array}$ & $\begin{array}{l}\text { Monitoring chart specifying (for each } \\
\text { indicator): unit of measurement and } \\
\text { foreseen effects }\end{array}$ \\
\hline Otranto Port Plan & $\begin{array}{l}\text { Identification of } 14 \text { monitoring } \\
\text { indicators }\end{array}$ & $\begin{array}{l}\text { Monitoring chart specifying (for each } \\
\text { indicator): environmental component and } \\
\text { relative regulating authority }\end{array}$ \\
\hline Taranto Port Plan & $\begin{array}{l}\text { Identification of } 24 \text { monitoring } \\
\text { indicators }\end{array}$ & $\begin{array}{l}\text { Monitoring chart specifying (for each } \\
\text { indicator): unit of measurement, relative } \\
\text { regulating authority, environmental } \\
\text { components and goals }\end{array}$ \\
\hline Termoli Port Plan & $\begin{array}{l}\text { Identification of } 18 \text { monitoring } \\
\text { indicators (the same as the state of } \\
\text { the environment) }\end{array}$ & $\begin{array}{l}\text { Monitoring chart specifying (for each } \\
\text { indicator): unit of measurement, source, } \\
\text { sustainability goals, phases (ex-ante, } \\
\text { on-going, ex-post) }\end{array}$ \\
\hline Vasto Port Plan & $\begin{array}{l}\text { Identification of } 30 \text { monitoring } \\
\text { indicators }\end{array}$ & $\begin{array}{l}\text { Monitoring chart specifying (for each } \\
\text { indicator): environmental components and } \\
\text { frequency }\end{array}$ \\
\hline
\end{tabular}

We can note that in four of the six case studies, some project alternatives were considered. In two cases, evaluations of alternatives based on the estimated values of specific indicators were carried out; in these two cases, a comparison with a "zero" alternative (no plan intervention) was made. In no cases were the multi-criteria evaluation methods or Geographic Information Systems used.

For the Strategic Environmental Assessment of Port Plans, it may instead be useful to consider approaches that combine Multi-Criteria Analysis and Multi-Groups Analysis with Geographical Information Systems (GIS). Integration of different evaluation models with GIS becomes decidedly important in the construction of a Spatial Decision Support System in which a variety of territorial information (social, economic and environmental) can be easily combined and related to the characteristics of the different options for territorial use, thereby facilitating the construction of appropriate indicators and improving effect forecasting, leading finally to a preference priority list of the various options. [40]. Integration of Multi-Criteria Analysis, Multi-Group Analysis and GIS can be remarkably useful when there are strong conflicts and when the role of local actors and their relations and goals can be considered in structuring elements in the process of information construction in a dynamic spatial evaluative model $[41,42]$. In recent years, theoretical research and new technologies have improved the identification and implementation of integrated approaches for defining planning strategies and actions. 


\section{The Integrated Spatial Assessment (ISA) Approach}

Taking into account the aforementioned considerations, it is important to identify an integrated approach for port-planning evaluation in which the process and its phases can take into account local needs and guide situated decision-making processes.

The proposal of a multi-methodological evaluative framework - in which interdisciplinarity and transdisciplinarity are essential and that includes the cognitive skills and habits of the stakeholders and experts involved in mutual, joint and dynamic learning processes - can help generate more efficient and effective results than sector-specific approaches.

A multi-methodological decision support system can be considered as the integration of a dynamic system (able to consider the time evolution), a deliberative system (able to include all the stakeholders), a comprehensive system (able to take account of quantitative and qualitative aspects related to different components) and a spatial system (able to identify the territorial effects also through their visualization) [32]. According to this approach, a multi-methodological decision support system should be characterized by the interaction of Knowledge Base (KB), Relational Database Management System (RDBMS), Graphical User Interface (GUI), Geographic Information System (GIS), Multi-Criteria Analysis (MCA), and Multi-Group Analysis (MGA), where the application of GIS is combined with evaluation tools and Planning Support Systems (PSS). At the same time, PSS can include visualization tools that make it possible to get a 3-D, visual sense of what one alternative future might look like; sketch-planning tools that allow users to enter rules and visualize the outcome of those assumptions; simulation systems trying to model the behavior of urban agents and the potential effects of alternative policy actions.

Taking into account potentials and critical aspects of a multi-methodological framework, it can be relevant to identify an integrated approach where the decision-making process and its phases are able to identify and understand different and conflicting local needs and guide the planning process. The proposal of a multi-methodological framework that includes the cognitive skills and habits of stakeholders and experts involved in mutual, joint and dynamic learning processes, can help generate more efficient and effective results than sectoral approaches, where interdisciplinarity and transdisciplinarity are essential.

At the same time, the ongoing debate in the environmental assessment literature about the contribution of SEA to public decision-making [43] and how this can be understood and enhanced by better incorporating insights from policy analysis, planning theory and political sciences, frames SEA as a support to construction and elaboration of a strategic decision-making process, with a relevant role in complex decision-making contexts.

Taking into account the above perspective, in order to identify a multi-methodological decision support system, the Integrated Spatial Assessment (ISA) approach is proposed [32,44]. It is an approach in which the recognition of tangible and intangible values is the basis for collective decision-making that includes the development of goals, the sharing of knowledge, negotiation and compromise, problem posing and problem solving, the evaluation of needs, and the definition of goals.

The proposed approach can help communities clarify values, be more adaptive and proactive, respond to change, set personal and collective goals, and participate in the decision-making process. At the same time, the application of spatial tools is useful in identifying territorial references linking 
values and planning choices [45-49]. In particular, the integration of Multi-Criteria Analysis (MCA), Multi-Group Analysis (MGA) and Geographical Information Systems (GIS) is remarkably fruitful in planning processes in which the role of local agents and their relationships and goals can be considered structuring elements in a process of information construction within a dynamic spatial evaluative model [50-53].

Compared to traditional forms of GIS use, it might be possible to evaluate data relating not only to existing conditions but also:

1. the spatial characteristics of proposed options (alternatives);

2. the temporal modification of data following the implementation of the options;

3. the expressed preferences of local agents;

4. the conflict analysis among various stakeholders;

5. the evaluation of various options in order to obtain a preference priority list.

Considering the previous steps, we defined a methodological process that combines the contribution of different methods and tools. Indeed, many experiences in different sectors have been undertaken in which Multi-Criteria Analysis, Multi-Group Analysis and GIS have been developed using different evaluation methods. This type of integration creates a "spatial multi-criteria and multi-group analysis" (Figure 2).

Figure 2. Integrated Spatial Assessment (ISA) approach.

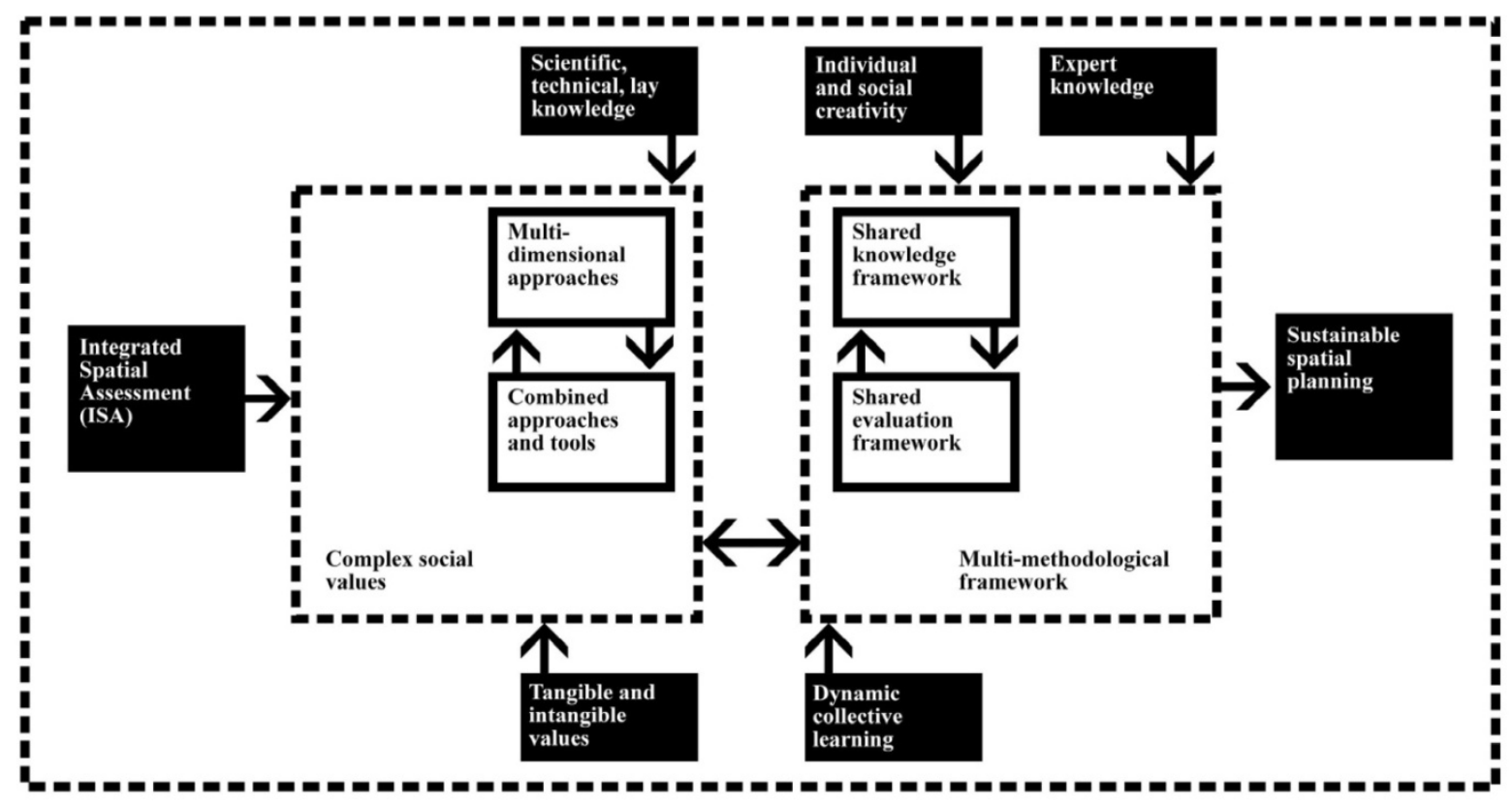

We propose to extend this integration in an "integrated assessment" approach in order to consider not only the technical aspects of the decision-making problem but also the involvement and participation of the local community in planning choices (Figure 3). 
Figure 3. Integrated Spatial Assessment (ISA) approach in SEA process.

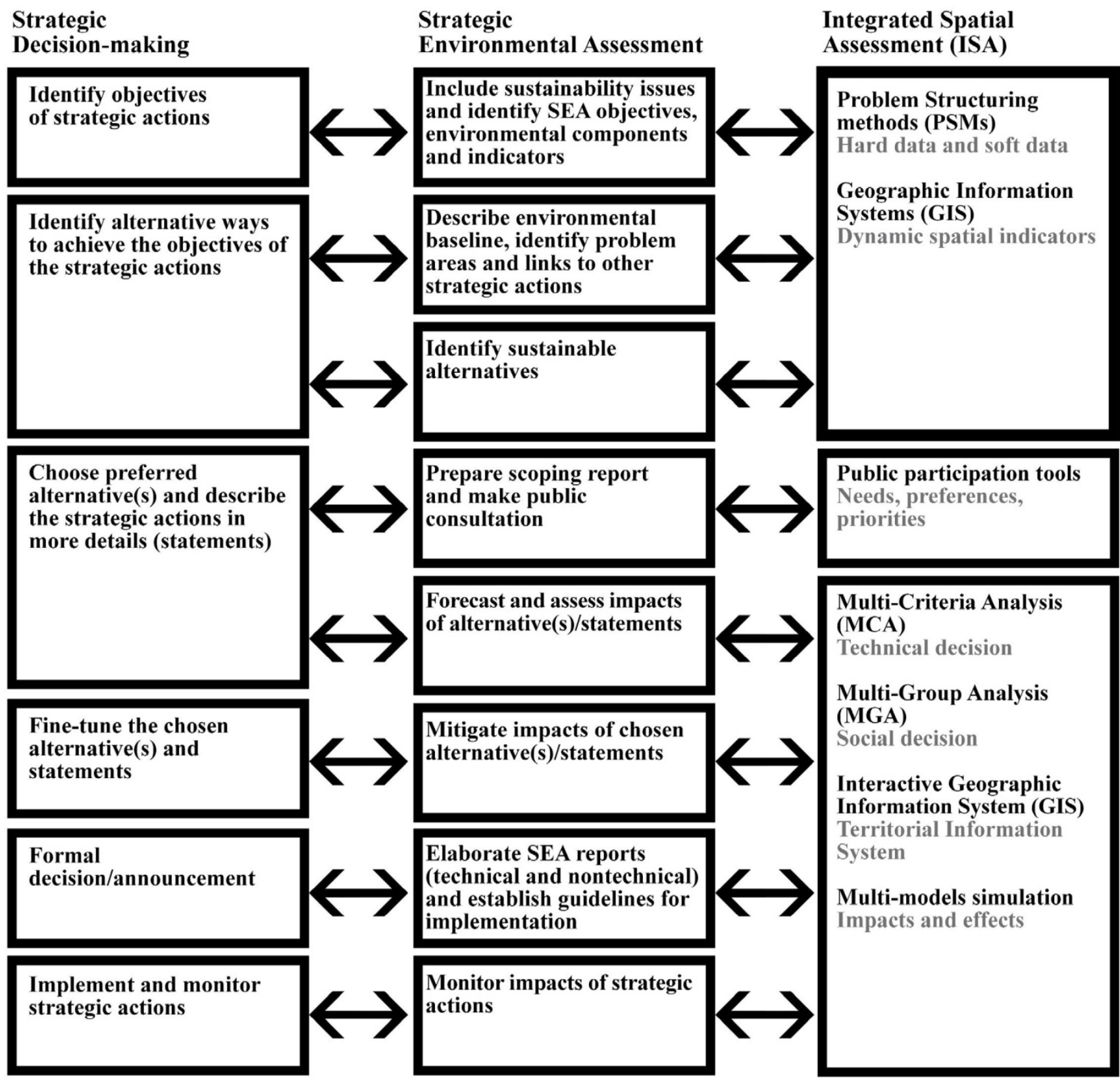

The methodological process proposed combines the contribution of different methods and tools in order to integrate strategic decision-making process and SEA process [54]. SEA steps interact with the different phases of a strategic decision-making process and can be implemented by the evaluative tools identified in ISA approach.

The first methodological step is oriented to the construction of an aware shared knowledge, able to support the identification of local potentials and critical aspects, combining hard data and soft data, and represent multidisciplinary knowledge by dynamic spatial indicators, able to use the spatial dimension for constructing indicators for aiding decision-making. Indeed, dynamic spatial indicators emphasize a transversal and systemic viewpoint, and are indispensable for tackling the territorial complexity and the related issues of sustainable development, while overcoming the limitations of an analysis and action scale. The spatial dimension can be a useful tool for aiding cooperation in the understanding of 
a territory's development issues, contributing to a deep awareness by the stakeholders involved and to a systemic perspective, where an interactive and iterative approach is essential.

The application of Problem Structuring Methods (PSMs) combined with Public Participation Tools can be useful for the construction of a shared knowledge framework. The PSMs are methods that provide a useful support to information structuring within Decision Support Systems, and are able to deal with a variety of nonstructured problems and situations, prevailing over traditional approaches and following communicative conceptions of planning [55]. Nonstructured problems are characterized by a multiplicity of agents, a multiplicity of points of view incommensurable interests, important intangible values, and uncertainty. In these situations, through PSMs, it is possible to visualize a problem so that participants can clear up their positions and converge in one or more potential issues aimed at building consensus. Through PSMs, it is possible to represent graphically the complexity of the issues examined considering hard data and soft data, explore the space solutions, compare discrete alternatives, face uncertainty in terms of "possibilities" and "scenarios," and model cause-effect relations useful in facilitated groups and workshops.

The elaboration of a GIS with dynamic spatial indicators can lead to the development of a systemic model of the dynamics of territorial transformations, drawing up a multidimensional systemic vision that can be shared with the different users (decision-makers and decision-receivers). This means improves the understanding of the local interactions and processes and select indicators that offer an integrated vision of the issues of territorial development, able to be a model of the territorial complexity.

The second methodological step is related to the identification of needs, preferences and priorities by the implementation of different and combined public participation tools. In particular, PSMs could be combined with the PPGIS, defined as the use of GIS to broaden public involvement in policy making, as well as the value of GIS to promote the goals of nongovernmental organizations, grassroots groups and community-based organizations [56-58]. PPGIS is meant to bring the academic practices of GIS and mapping to a local level in order to promote knowledge production. The idea behind PPGIS is empowerment and inclusion of marginalized populations, who have little space in the public arena, through geographical technology education and participation. PPGIS uses and produces digital maps, satellite imagery, sketch maps, and many other spatial and visual tools, to change geographical involvement and awareness at a local level. The local participatory management of urban neighborhoods usually comes from "claiming the territory," and has to be made compatible with national or local authority regulations in managing and planning urban territory $[59,60]$.

The third methodological step combines Multi-Criteria Analysis for supporting a technical decision, Multi-Group Analysis for helping in a social decision, and interactive GIS for a Territorial Information System in order to overcome the limitations of specific techniques through the application of different methods coming from different disciplines and defining a more complete and integrated framework of analysis and evaluation, which is able to elaborate multi-model simulations for the assessment of impacts and effects.

Spatial multi-criteria decision-making problems typically involve a set of geographically defined alternatives from which a choice of one or more alternatives is made with respect to a given set of evaluation criteria [61,62]. In particular, spatial multi-criteria analysis is very different from conventional multi-criteria techniques due to the inclusion of an explicit geographic component. 
It requires information concerning criterion values and geographic locations of alternatives in addition to decision-makers' preferences for a set of evaluation criteria [63-65]. This means that results of the analysis depend not only on the geographic distribution of attributes but also on the value judgments involved in the decision-making process [66,67]. Therefore, three considerations are fundamental for spatial multi-criteria analysis: the GIS component (data acquisition, storage, etc.), the multi-criteria analysis component (aggregation of spatial data and decision-makers' preferences into discrete decision alternatives), and the multi-group analysis component (equity assessment and conflicts resolution) $[24,43,45-50]$. Spatial analysis combined with multi-criteria methods has been used in recent years to support evaluation, especially in the field of land-use planning. GIS was integrated with an outranking multi-criteria method called ELECTRE-TRI [41,51,68], or with multi-criteria analysis using Analytical Hierarchy Process (AHP), involving not only technical aspects, but also physical, economical, social, environmental and political aspects [69,70]. GIS and Multi-Criteria Analysis also provided better insight into the consequences of possible alternatives supporting stakeholders' participation, using the software package DEFINITE [71]. Indeed, integration between Multi-Criteria Analyses, Multi-Group Analyses and GIS can be useful when facing conflicts, taking into account the roles of the local agents, the existing relationships and preselected goals as structural parts of the information-building process within a dynamic spatial evaluation model. With respect to the traditional use of GIS, we can take into account data not only regarding existing conditions, but also the spatial characteristics of the proposed options, the change in data over time, elicitation of agents' preferences, conflict analysis, and the assessment of the effects of the different alternatives.

The proposed approach can represent an alternative way to answer to SEA theory and practice often based on a classical model of decision-making. Decision-making often encompasses negotiation between public decision makers and stakeholders, including activities that form part of policy-making processes, such as knowledge generation. Interaction among scientific knowledge, technical knowledge and lay knowledge represent an opportunity to face many uncertainties and different complexity levels [72], contributing to generate new shared knowledge able to improve decisionmaking processes and putting SEA in the wider perspective of complex decision-making contexts.

\section{Conclusions}

The analysis of the Environmental Reports prepared during the Strategic Environmental assessment of six port plans in Italy has sought to outline the progress made in the most commonly used approaches and tools. The goal is to identify both the advantages and weaknesses of the different approaches, as well as the effectiveness of the techniques and tools.

Taking into account the requirements of European Directive 42/2001/EC [2], the points of Annex I were analyzed through the comparison of the six port plan case studies and some general considerations for improving new SEA processes can be made. In general, the Environmental Reports can be excessively descriptive and not geared towards the specific selection of the required information and the development of relevant and truly significant indicators. In many cases, interaction between the different SEA phases is viewed as linear rather than circular, reducing opportunities for integration between different knowledge bases and limiting integration with planning phases. 
The need for common approaches to planning and evaluation becomes evident in order to structure the selection of the goals that are pursued and that can lead to possible sustainable actions, considering a multifaceted knowledge framework that can reflect the complexity of the issues at hand, and allowing the assessment of alternatives and their effects as well as to define indicators useful in monitoring plan implementation [73-75].

It is clear that when and how SEA is applied is crucial in understanding its effectiveness which depends upon its alignment with, and embedding within, the planning process [76]. At the same time, in order to understand how to structure and improve integrated planning/evaluation of port plans, it is important to consider how to implement the interaction between the assessment context, the assessment process and assessment methods; how to select different approaches and techniques; and how to choose them considering the specificity of the decision-making context.

The proposed ISA approach allows us to explore integrated evaluation tools helping to recognize their technical effectiveness and, at the same time, improving the transparency of the evaluation process that can lead to decisions reflecting different needs and expectations [77-81]. In this light, ISA can be a useful tool for decision-making insofar as it includes technical and political evaluations and refers to articulated and complex value systems within a conflicting and changing reality, especially with reference to SEA Port Plans. The identification of a multi-methodological evaluative framework can contribute to support a decision-making process that allows for the analysis of the complexity of human decisions in a flexible environment in which collective knowledge and dynamic learning play significant roles in decision-making, as well as for the possibility to explore the definition of spatial strategies in keeping with sustainable and complex values.

\section{Conflict of Interest}

The authors declare no conflict of interest.

\section{References}

1. Therivel, R.; Partidário, M.R. The Practice of Strategic Environmental Assessment; Earthscan: London, UK, 1992.

2. European Parliament; Council of the European Union. Directive 2001/42/EC of the European Parliament and of the Council of 27 June 2001 on the assessment of the effects of certain plans and programmes on the environment. Official Journal of the European Communities; L 197/30; EU: Luxembourg, Luxembourg, 2001.

3. Geneletti, D.; Bagli, S.; Napolitano, P.; Pistocchi, A. Spatial decision support for strategic environmental assessment of land use plans. A case study in southern Italy. Environ. Impact Asses. 2007, 27, 408-423.

4. McLauchlan, A.; João, E. The inherent tensions arising from attempting to carry out strategic environmental assessments on all policies, plans and programmes. Environ. Impact Asses. 2012, 36, 23-33.

5. Bina, O. A critical review of the dominant lines of argumentation on the need for strategic environmental assessment. Environ. Impact Asses. 2007, 27, 585-606. 
6. Wallington, T.; Bina, O.; Thissen, W. Theorising strategic environmental assessment: Fresh perspectives and future challenges. Environ. Impact Asses. 2007, 27, 569-584.

7. Cashmore, M.; Richardson, T.; Hilding-Ryedvik, T.; Emmelin, L. Evaluating the effectiveness of impact assessment instruments: Theorising the nature and implications of their political constitution. Environ. Impact Asses. 2010, 30, 371-379.

8. Carvalho Lemos, C.; Fischer, T.B.; Pereira Souza, M. Strategic environmental assessment in tourism planning-Extent of application and quality of documentation. Environ. Impact Asses. 2012, 35, 1-10.

9. Gachechiladze-Bozhesku, M.; Fischer, T.B. Benefits of and barriers to SEA follow-up-Theory and practice. Environ. Impact Asses. 2012, 34, 22-30.

10. Kontić, B.; Kontić, D. A viewpoint on the approval context of strategic environmental assessments. Environ. Impact Assess. Rev. 2012, 32, 151-155.

11. Vammen Larsen, S.; Kørnøv, L.; Wejs, A. Mind the gap in SEA: An institutional perspective on why assessment of synergies amongst climate change mitigation, adaptation and other policy areas are missing. Environ. Impact Asses. 2012, 33, 32-40.

12. Stojanovic, T.A.; Ormerod Smith, H.D.; Wooldridge, C.F. The impact of the Habitat Directive on European port operations and management. GeoJournal 2006, 65, 165-176.

13. European Parliament; Council of the European Union. Directive 1992/43/ECC of the European Parliament and of the Council of the 21 May 1992 on the conservation of natural habitats and of wild fauna and flora. Official Journal of the European Communities; L 206; EU: Luxembourg, Luxembourg, 1992.

14. European Parliament; Council of the European Union. Directive 1985/337/EC of the European Parliament and of the Council of 27 June 1985 on the assessment of the effects of certain public and private projects on the environment. Official Journal of the European Communities; L 175; EU: Luxembourg, Luxembourg, 1985.

15. Randazzo, G.; Lo Curzio, M.; Lanza, S. First steps in strategic environmental assessment (SEA) adoption for coastal planning in Sicily (South Italy). J. Coast Conserv. 2008, 12, 161-168.

16. Ng, A.K.Y.; Song, S. The environmental impacts of pollutants generated by routine shipping operations on ports. Ocean Coast. Manag. 2010, 53, 301-311.

17. Saxe, H.; Larsen, T. Air pollution from ships in three Danish ports. Atmos. Environ. 2004, 38, 4057-4067.

18. Perchinunno, P.; Rotondo, F.; Torre, C.M. The evidence of links between landscape and economy in a rural park. Int. J. Agr. Environ. Inform. Syst. 2012, 3, 72-85.

19. Gu, D.; Zhang, Y.; Fu, J.; Zhang, X. The landscape pattern characteristics of coastal wetlands in Jiaozhou Bay under the impact of human activities. Environ. Monit. Assess. 2007, 124, 361-370.

20. Parravicini, V.; Rovere, A.; Vassallo, P.; Micheli, F.; Montefalcone, M.; Morria, C.; Paoli, C.; Albertelli, G.; Fabiano, M.; Bianchi, C.N. Understanding relationships between conflicting human uses and coastal ecosystems status: a geospatial modeling approach. Ecol. Indic. 2012, 19, 253-263.

21. Partidário, M.R. Elements of an SEA framework-Improving the added-value of SEA. Environ. Impact Asses. 2000, 20, 647-663. 
22. Pischke, F.; Cashmore, M. Decision-oriented environmental assessment: An empirical study of its theory and methods. Environ. Impact Asses. 2006, 26, 643-662.

23. van der Sluijs, J.P. A way out of the credibility crisis of models used in integrated environmental assessment. Futures 2002, 34, 133-146.

24. Munda, G. Social Multi-Criteria Evaluation for a Sustainable Economy; Springer: New York, NY, 2008.

25. Fischer, T.B. Theory and Practice of Strategic Environmental Assessment: Towards a More Systematic Approach; Earthscan: London, UK, 2007.

26. Finnveden, G.; Nilsonn, M.; Johansonn, J.; Personn, Å.; Moberg, Å.; Carlsonn, T. Strategic environmental assessment methodologies-Application within the energy sector. Environ. Impact Asses. 2003, 23, 91-123.

27. Malczewski, J. GIS and Multicriteria Decision Analysis; JohnWiley \& Sons: New York, NY, 1999.

28. Al-Shalabi, M.A.; Bin Mansor, S.; Bin Ahmed, N.; Shiriff, R. GIS based multicriteria approaches to housing site suitability assessment. In Shaping the Change, Proceedings of the XXIII FIG Congress, Munich, Germany, 8-13 October 2006.

29. Nekhay, O.; Arriaza, M.; Guzmán-Álvarez, J.R. Spatial analysis of the suitability of olive plantations for wildlife habitat restoration. Comput. Electron. Agr. 2009, 65, 49-64.

30. Şener, Ş.; Şener, E.; Nas, B.; Karagüzel, R. Combining AHP with GIS for landfill site selection: A case study in the Lake Beyşehir catchment area (Konya, Turkey). Waste Manag. 2010, 30, 2037-2046.

31. Vizzari, M. Spatial modelling of potential landscape quality. Appl. Geogr. 2011, 31, 108-118.

32. Cerreta, M.; De Toro, P. Integrated Spatial Assessment (ISA): A multi-methodological approach for planning choices. In Advances in Spatial Planning; Burian J., Ed.; InTech: Rijeka, Croatia, 2012; pp. 77-108.

33. Autorità Portuale di Cagliari. Rapporto Ambientale; Valutazione Ambientale Strategica del Piano Regolatore Portuale: Cagliari, Italy, 2010.

34. Regione Marche. Rapporto Ambientale; Valutazione Ambientale Strategica del Piano Regolatore Portuale di Numana: Numana, AN, Italy, 2011.

35. Comune di Otranto. Rapporto Ambientale; Valutazione Ambientale Strategica del Piano Regolatore Portuale: Otranto, LE, Italy, 2011.

36. Autorità Portuale di Taranto. Rapporto Ambientale; Valutazione Ambientale Strategica del Piano Regolatore Portuale: Taranto, Italy, 2011.

37. Regione Molise. Rapporto Ambientale; Valutazione Ambientale Strategica del Piano Regolatore Portuale di Termoli: Termoli, CB, Italy, 2011.

38. Regione Molise. Rapporto Ambientale; Valutazione Ambientale Strategica del Piano Regolatore Portuale di Vasto: Vasto, CH, Italy, 2011.

39. European Parliament; Council of the European Union. Directive 1979/409/EEC of the European Parliament and of the Council of the 2 April 1979 on the conservation of wild birds. Official Journal of the European Communities; L 103; EU: Luxemburg, Luxemburg, 1979.

40. Fusco Girard, L. Sustainability, creativity, resilience: Toward new development strategies of port areas through evaluation processes. Int. J. Sustain. Dev. 2010, 13, 17-30. 
41. Joerin, F.; Musy, A. Land management with GIS and multicriteria analysis. Int. Trans. Oper. Res. 2000, 7, 67-78.

42. Thirumalaivasan, D.; Karmegam, M.; Venugopal, K. AHP-DRASTIC: Software for specific aquifer vulnerability assessment using DRASTIC model and GIS. Environ. Modell. Softw. 2003, 18, 645-656.

43. Runhaar, H. Putting SEA in context: A discourse perspective on how SEA contributes to decision-making. Environ. Impact Asses. 2009, 29, 200-209.

44. Cerreta, M.; De Toro, P. Integrated Spatial Assessment for a creative decision-making process: A combined methodological approach to Strategic Environmental Assessment. Int. J. Sustain. Dev. 2010, 13, 17-30.

45. Montrone, S.; Perchinunno, P.; Torre, C.M. Analysis of positional aspects in the variation of real estate values in an Italian Southern Metropolitan area. Lect. Notes Comput. Sci. 2010, 6016, $17-31$.

46. Geneletti, D. An approach based on spatial multicriteria analysis to map the nature conservation value of agricultural land. Environ. Manag. 2007, 83, 228-235.

47. Kain, J.-H.; Söderberg, H. Management of complex knowledge in planning for sustainable development: The use of multi-criteria decision aids. Environ. Impact Asses. 2008, 28, 7-21.

48. Murgante, B.; Danese, M. Urban versus Rural: The decrease of agricultural areas and the development of urban zones analyzed with spatial statistics. Special Issue on "Environmental and agricultural data processing for water and territory management". Int. J. Agr. Environ. Inform. Syst. 2011, 2, 16-28.

49. Fichera, C.R.; Modica, G.; Pollino, M. GIS and remote sensing to study urban-rural transformation during a fifty-year period. Lect. Notes Comput. Sci. 2011, 6782, 237-252.

50. Jankowski, P. Integrating geographical information systems and multiple criteria decision-making methods. Int. J. Geogr. Inform. Syst. 1995, 9, 251-273.

51. Joerin, F.; Theriault, F.; Musy, A. Using GIS and outranking multicriteria analysis for land-use suitability assessment. Int. J. Geogr. Inf. Sci. 2001, 15, 153-174.

52. Gontier, M.; Mörtberg, U.; Balfors, B. Comparing GIS-based habitat models for applications in EIA and SEA. Environ. Impact Asses. 2010, 30, 8-18.

53. González, A.; Gilmer, A.; Foley, R.; Sweeney, J.; Fry, J. Applying geographic information systems to support strategic environmental assessment: Opportunities and limitations in the context of Irish land-use plans. Environ. Impact Asses. 2011, 31, 368-381.

54. Pischke, F.; Cashmore, M. Decision-oriented environmental assessment: An empirical study of its theory and methods. Environ. Impact Asses. 2006, 26, 643-662.

55. Rosenhead, J.; Mingers, J. Rational Analysis for a Problematic World Revisited; John Wiley \& Sons: Chichester, UK, 2001.

56. Gauthier, M.; Simard, L.; Waaub, J.-P. Public participation in strategic environmental assessment (SEA): Critical review and the Quebec (Canada) approach. Environ. Impact Asses. 2011, 31, 48-60.

57. Sieber, R. Public participation and geographic information systems: A literature review and framework. Ann. Assoc. Am. Geogr. 2006, 96, 491-507. 
58. Tilio, L.; Scorza, F.; Lanza, V.; Murgante, B. Open source resources and Web 2.0 potentialities for a new democratic approach in programming practices. LNAI 2009, 5736, 228-237.

59. McCall, M.K. Seeking good governance in participatory-GIS: A review of processes and governance dimensions in applying GIS to participatory spatial planning. Habitat Int. 2003, 27, 549-573.

60. Murgante, B.; Tilio, L.; Lanza, V.; Scorza, F. Using participative GIS and e-tools for involving citizens of Marmo Platano-Melandro area in European programming activities. Special issue on "E-Participation in Southern Europe and the Balkans". Journal of Balkans and Near Eastern Studies 2011, 13, 97-115.

61. Jankowski, P. Integrating geographical information systems and multiple criteria decision-making methods. Int. J. Geogr. Inf. Syst. 1995, 9, 251-273.

62. Malczewski, J. GIS-based land-use suitability analysis: A critical overview. Progr. Plann. 2004, 62, 3-65.

63. Scolozzi, R.; Geneletti, D. A multi-scale qualitative approach to assess the impact of urbanization on natural habitats and their connectivity. Environ. Impact Asses. 2012, 36, 9-22.

64. Schetke, S.; Haase, D.; Kötter, T. Towards sustainable settlement growth: A new multi-criteria assessment for implementing environmental targets into strategic urban planning. Environ. Impact Asses. 2012, 32, 195-210.

65. Strager, M.P.; Rosenberger, R.S. Incorporating stakeholder preferences for land conservation: Weights and measures in spatial MCA. Ecol. Econ. 2006, 58, 79-92.

66. Fusco Girard, L.; Torre, C.M. The use of Ahp in a multiactor evaluation for urban development programs: A case study. Lect. Notes Comput. Sci. 2012, 7334, 157-167.

67. Geneletti, D. Combining stakeholder analysis and spatial multicriteria evaluation to select and rank inert landfill sites. Waste Manag. 2010, 30, 328-337.

68. Joerin, F.; Theriault, F.; Musy, A. Using GIS and outranking multicriteria analysis for land-use suitability assessment. Int. J. Geogr. Inform. Sci. 2001, 15, 153-174.

69. Kheirkhah Zarkesh, M.M.; Ghoddusi, J.; Zaredar, N.; Soltani, M.J.; Jafari, S.; Ghadirpour, A. Application of spatial analytical hierarchy process model in land use planning. J. Food Agr. Environ. 2010, 8, 970-975.

70. Yang, F.; Zeng, G.; Du, C.; Tang, L.; Zhou, J.; Li, Z. Spatial analyzing system for urban land-use management based on GIS and multi-criteria assessment modeling. Prog. Nat. Sci. 2008, 18, 1279-1284.

71. Janssen, R.; Goosen, H.; Verhoeven, M.L.; Verhoeven, J.T.A.; Omtzigt, A.Q.A.; Maltby, E. Decision support for integrated wetland management. Environ. Modell. Softw. 2005, 20, 215-229.

72. Funtowicz, S.O.; Ravetz, J. Science for the post-normal age. Futures 1993, 25, 739-755.

73. Selicato, M.; Torre, C.M.; La Trofa, G. Prospect of integrated monitoring: A multidimensional approach. Lect. Notes Comput. Sci. 2012, 7334, 144-156.

74. Wu, J.; Chang, I.-S.; Bina, O.; Lam, K.-C.; Xu, H. Strategic environmental assessment implementation in China-Five-year review and prospects. Environ. Impact Asses. 2011, 31, $77-84$. 
75. Di Fazio, S.; Modica, G.; Zoccali, P. Evolution trends of land use/land cover in a Mediterranean forest landscape in Italy. Lect. Notes Comput. Sci. 2011, 6782, 284-299.

76. van Buuren, A.; Nooteboom, S. Evaluating strategic environmental assessment in The Netherlands: Content, process and procedure as indissoluble criteria for effectiveness. Impact Assess. Proj. Apprais. 2009, 27, 145-154.

77. Cerreta, M.; Panaro, S.; Cannatella, D. Multidimensional spatial decision-making process: Local shared values in action. Lect. Notes Comput. Sci. 2012, 7334, 54-70.

78. Cerreta, M.; Mele, R. A landscape complex value map: integration among soft values and hard values in a spatial decision support. Lect. Notes Comput. Sci. 2012, 7334, 653-659.

79. Fusco Girard, L.; De Toro, P. Integrated spatial assessment: A multicriteria approach to sustainable development of cultural and environmental heritage in San Marco dei Cavoti, Italy. Cent. Eur. J. Oper. Res. 2007, 15, 281-299.

80. Vizzari, M. Spatio-temporal analysis using urban-rural gradient modelling and landscape metrics. Lect. Notes Comput. Sci. 2011, 6782, 103-118.

81. Fichera, C.R.; Modica, G.; Pollino, M. Land Cover classification and change-detection analysis using multi-temporal remote sensed imagery and landscape metrics. Italian Journal of Remote Sensing 2012, 45, 1-18.

(C) 2012 by the authors; licensee MDPI, Basel, Switzerland. This article is an open access article distributed under the terms and conditions of the Creative Commons Attribution license (http://creativecommons.org/licenses/by/3.0/). 